\title{
UNEXPECTED CONNECTIONS: NEW JERSEY MANUSCRIPTS IN THE RUTGERS AND PRINCETON LIBRARIES
}

\section{BY FERNANDA PERRONE}

Dr. Perrone is an assistant archivist in the Department of Special Collections and Archives and is in the master's program in library science at Rutgers, The State University of New Jersey.

The development of the manuscript collections of Princeton and Rutgers reflects the differing histories of the two universities. Princeton developed a research collection partially based on the areas of academic strengths of its university departments, augmented by the gifts of alumni, private collectors, and purchases. In contrast, Rutgers, as the state university, developed a strong regional collection. Princeton acquired New Jersey materials as well, in many cases through faculty and alumni or by virtue of its location, rather than through conscious effort. Although the New Jersey materials at Princeton are not as well known or as frequently used as other parts of the collection, they include valuable materials, some of which are complementary to collections at Rutgers which are heavily used by research scholars, students, local historians, and genealogists. The reasons why Princeton and Rutgers acquired these collections can be understood by looking at the history of the collecting policies of the two institutions.

In the early 1890 s, Princeton University acquired its first manuscripts, which were related to the history of the university. The transformation of the College of New Jersey, as Princeton was originally named, into Princeton University in 1896 provided the impetus to collect materials which would support the university's academic programs. During the period 1890 to 1940 , Princeton's library collected mainly in the areas of classical, medieval, and Near Eastern manuscripts, highlighted by the gifts of Robert Garrett in the 1930s. The emphasis shifted toward American history when Julian Boyd was appointed university librarian in 1940. Boyd had been director of the New York State Historical Society and librarian of the Pennsylvania Historical Society before coming to Princeton. As university librarian, he collected extensively in the area of eighteenth-century American history, English and 
American literature, and publishing history. In 1944, he began editing the papers of Thomas Jefferson, continuing until his death in $1980{ }^{1}$

The next phase in the history of the manuscript collection began with the donation of the papers of John Foster Dulles (Class of 1908) and of Bernard Baruch in 1964. These two acquisitions became the nucleus of a collection of twentieth-century American statecraft and public policy, one of the largest public affairs collections in the country. First housed in a wing of the Firestone Library, in 1976 the collection was able, through the generosity of the Seeley G. Mudd Fund, to move to a purpose-built structure, the Seeley G. Mudd Manuscript Library. The original collections were joined by the papers of James Forrestal, Allen W. Dulles, Raymond B. Fosdick, Adlai Stevenson, and many other seminal figures in twentieth-century public policy. ${ }^{2}$

Today the Firestone Library at Princeton houses approximately 750 manuscript collections, and 180 are preserved in the Mudd Library. The strengths of the Firestone collections are medieval and Islamic manuscripts; English and American literature, including the Morris L. Parrish Collection of Victorian Novelists, and the papers of F. Scott Fitzgerald, Ernest Hemingway, Booth Tarkington, and others; and American publishing history. Other areas of strength are eighteenthcentury American history; jurisprudence, including the papers of Supreme Court justices William O. Douglass and John Marshall Harlan; anthropology; and the history of science.

Rutgers as well accumulated a few manuscripts during the nineteenth century. Some were gifts of alumni and others associated with Rutgers College. These early manuscripts were stored in drawers and various other places in the college library, which moved from a room in Old Queen's to the Kirkpatrick chapel in 1874. At this time, the library was only open two hours a day for students to borrow and return books. With the appointment of Irving S. Upson as the first person to be expressly designated librarian in 1884 , library hours were extended, and modern techniques of cataloging and arrangement were introduced. The library acquired its own building, Voorhees Hall, in 1904, which was expanded in 1926. In 1907, George A. Osborn, a Rutgers College graduate of 1897 who had been employed in the library first as an assistant, then as acting head, was appointed university librarian.

During Osborn's nearly forty-year tenure, the library's collections were greatly expanded, and the original decision to collect New Jersey material was made. The gift of the papers of Rutgers alumnus, trustee, and benefactor James Neilson after his death in 1936, added over 19,000 
items to the library, including letters, receipts, contracts, leases, and account books which documented the social, industrial, and commercial development of New Jersey, as well as documenting the Revolutionary War in the state. In the 1930s, the manuscripts were stored in several locations on one side of the building. Among them were account books and other materials bound in volumes. Donald Sinclair, who had begun working in the library as a student in 1935, was given the painstaking task of labeling and recording the bound manuscripts, as well as organizing the loose ones.

George Osborn retired in 1944 and Donald F. Cameron was appointed university librarian. Cameron, who was born in Scotland, was a professor of English, and had been instrumental in founding both the Rutgers University Press in 1937 and the Rutgers University Research Council during the Second World War. In 1938, Donald Cameron also helped establish the Friends of the Library, which sought to "arouse an interest in Rutgers and the state of New Jersey and so make it possible for the university library to acquire as much material relating to New Jersey as possible." 3

Cameron sought to achieve this goal by setting up the department of Special Collections, which included rare books, manuscripts, and printed materials, much of which pertained to New Jersey. A Douglass graduate, Virginia Burnett, was appointed head of manuscripts, and Donald Sinclair, who returned from the war in January 1946, was made curator of Jerseyana. Burnett was an avid local historian, who did research on Morristown local history and on outstanding New Jersey women, among other topics. Upon her sudden death in 1947, Donald Sinclair became head of the new department, where he remained until his retirement in 1982. Sinclair felt it was particularly important to collect material documenting the social history of New Jersey. He combed the state in search of family papers; diaries; and the records of schools, clubs, religious and social welfare organizations; as well as more traditional manuscripts documenting the state's political history. Under his leadership, the New Jersey collection became one of the premier regional archives in the country. In 1981, it was renamed the Sinclair New Jersey Collection.

Today Rutgers University owns over 3,000 manuscript collections, totaling over five million items. Significant New Jersey collections include the papers of Lewis and Robert Hunter Morris, Walt Whitman, and the official records of Woodbridge and Piscataway Townships. Although New Jersey remains the primary focus of the manuscript 
collection, other areas of strength have been developed including: labor and consumer history; women's professional associations; Westerners in Japan during the Meiji period; off-Broadway theater; and Latin American politics. Although many of its labor collections are New Jerseybased, Rutgers is also the official repository for the archives of the International Union of Electrical Workers, and possesses the records of the National Maritime Union of America, New York's American Labor Party (1947-1956), and the New Democratic Coalition of New York (1959-present). In addition to the records of the Consumer's League of New Jersey, the twentieth-century consumer's movement is documented by the papers of consumer advocate Sidney Margolius and National Consumer's League president Erma Angevine, and of Consumers' Research, one of the pioneers in product testing. Women's organizations represented in the archives include the New Jersey Welfare Council, the Sheltering Arms Children's Service, and other social welfare organizations; the Women's Caucus for Art; the New York Feminist Art Institute; the National Women's Education Fund; and the interdisciplinary feminist journal SIGNS. The area of Westerners in Japan is highlighted by the papers of William Griffis - the Rutgers graduate who lived in, worked in, and spent his life writing about Japan. Literary manuscripts include the J. Alexander Symington Collection of Swinburne and his circle, the Jack Kriendler collection of literary manuscripts by contemporary American writers, the papers of the playwright Paul Foster, and the papers of novelist and art critic Janet Hobhouse. Twentieth-century Latin American cultural and political movements are represented by the records of the Pan American Women's Association and the Inter-American Association for Democracy and Freedom.

There is no clear dividing line at Rutgers between the New Jersey Collection and the new collecting areas. Many New Jersey figures achieved national prominence, and certain events which took place in New Jersey were significant in the history of the country as a whole. At Princeton however, the New Jersey materials have tended to become marginalized. The following pages will describe several significant New Jersey collections at Princeton, and when possible, relate them to complementary collections at Rutgers.

\section{Eighteenth-and Nineteenth-Century Manuscripts}

An important New Jersey collection in the Firestone Library dating from the colonial period is comprised of the papers of James Alexander 
(1691-1756). Alexander, a collateral descendent of the Scottish Earls of Stirling, came to America after having fought in the 1715 Jacobite uprising. Trained as a civil engineer, Alexander was quickly made surveyor-general of New Jersey. He then took up the study of law and was made attorney general of the colony in 1723 . The versatile Alexander married a wealthy widow, Mary Provoost, and helped her continue to run the successful business which had belonged to her first husband.

Along with his friend and political ally Lewis Morris, Alexander sat on the Council, the upper house of the colonial legislature, in both New Jersey and New York and was a power on the East and West Jersey Board of Proprietors. The proprietors were a group of entrepreneurs who had bought the title to the lands originally granted to Lord John Berkeley and Sir George Carteret - the lands which made up the colony of New Jersey. In the mid-eighteenth century, the most pressing issue in New Jersey politics was ownership of land. James Alexander used his considerable litigation skills in defending the rights of the proprietors, attempting to evict settlers who held supposedly invalid titles. These eviction attempts led to violent uprisings in the 1740s and 1750s. In 1745, with Robert Hunter Morris, he researched and wrote the Elizabethtown Bill in Chancery in defense of proprietary rights. Later, Alexander supported Governor Belcher in defending New Jersey's claims in a border dispute with New York.

The Firestone Library houses ten folio-sized bound volumes of Alexander's letters and other documents, mostly pertaining to his legal practice. The collection includes Indian deeds, surveys, and a "Copy of the Jersey Commission for Running the Division Line betwixt the Province of New Jersey and New York," dated 1688, along with petitions and correspondence regarding land riots and those arrested during land disputes. Rutgers, on the other hand, possesses the papers of Alexander's associate Lewis Morris (1671-1746), and his son Robert Hunter Morris (1700-1764), who also served on the Council and became the chief justice of New Jersey. Lewis Morris had been a power in New Jersey for almost fifty years when he became the first governor of the colony after its separation from New York in 1738. The Rutgers collection includes personal, legal, governmental, and business papers, along with some of Morris' verse - he was an amateur poet. ${ }^{4}$ Taken together, the Alexander and Morris collections are valuable resources for those interested in the history of the colony.

Because of Julian Boyd's interest in eighteenth-century American history, the Princeton library possesses several collections from the 
Revolutionary War era, such as the papers of Edward Livingston and the Livingston family of New York, and the Boudinot family of New Jersey. Elias Boudinot (1740-1821) was, like James Alexander, a prominent attorney. Along with William Livingston, who became the first governor of the state, he was part of the radical Elizabethtown junto, early supporters of the Revolution. The two men were members of New Jersey's most influential committee of correspondence, formed in 1774. During the Revolutionary War, Boudinot served from 1777 to 1778 as commissioner of prisoners, many of whom were loyalists. In 1778, Boudinot was elected as representative of New Jersey to the Continental Congress, the body that governed the colonies during the Revolution. Boudinot modestly wrote to his wife in Basking Ridge:

I have never aimed at any publick Employment, nor even had a desire of entering into political consequence....I was called to my present Employment not from any desire of increasing either my wealth or Importance, but from abhorrence of being an Idle spectator of my country. ${ }^{5}$

Boudinot nevertheless went on to hold a number of political offices. From 1782 to 1783 , he was elected president of the Continental Congress then sitting in Princeton. He served as representative of New Jersey in the newly created House of Representatives from 1789 to 1795 , when he was appointed director of the mint in Philadelphia.

Although the Boudinot family papers at both Rutgers and Princeton are relatively small collections, they each contain letters illuminating the politics of the day. Both collections also include the papers of other family members such as Boudinot's brother Elisha, and remarkably candid, affectionate letters between Elias Boudinot and his wife Hannah Stockton. In conjunction with the Boudinot family papers held at the Historical Society of Pennsylvania and the New Jersey Historical Society, these collections provide rich material for researchers.

More significant than the Boudinot papers however, are the papers of William Paterson, New Jersey senator, governor, and Supreme Court Justice. Rutgers possesses a large collection, and Princeton also has significant holdings, as do William Paterson College, the New Jersey Historical Society, and the Library of Congress. William Paterson (17451806) was born in Antrim in the north of Ireland and emigrated to America with his family at the age of two. His father eventually owned a prosperous general store in Princeton, enabling William to attend the university, where he always, however, felt conscious of his inferior social status. After his graduation in 1763, Paterson was apprenticed to study 
law with Richard Stockton, later one of the signers of the Declaration of Independence. Although never a radical or a democrat, Paterson became a supporter of the Patriot cause. Like Boudinot, he became a delegate to the first provincial congress in 1775 and later served as its secretary. In 1776, he was appointed the first attorney general of New Jersey. Paterson hoped to remain in private practice after the war, but in 1787 , he was chosen to lead the New Jersey delegation to the constitutional convention. In early July, while the convention wrangled over the problem of how to balance the interests of the large states with those of the small states, Paterson wrote to his wife Euphemia in New Brunswick:

The Heat here is and has been intense. Philadelphia is, I think, the warmest place I have been in....I am under great apprehensions respecting my Apple Trees. ${ }^{6}$

Paterson would, however, play a key role in the convention; he was the author of the New Jersey Plan, which resulted in the compromise whereby although states were represented proportionately by population in the House of Representatives, each state was given equal representation in the Senate, which benefited small states like New Jersey. Fittingly, Paterson was elected senator himself in 1788, although he stepped down in 1791 to become the second governor of the state of New Jersey. As governor, Paterson began the huge project of revising and codifying the state's laws, publishing the Laws of the State of New Jersey in 1800, a draft copy of which is in the Department of Special Collections and Archives at Rutgers. In 1793, Washington appointed Paterson to the United States Supreme Court, where he sat until his death in 1806, participating in several cases which helped set precedents for the principle of judicial review.

The Paterson collection at Rutgers includes personal and business correspondence, legal papers, and political essays from the period 1766 to 1804 . Paterson was a prolific writer of newspaper essays which were published under various pseudonyms. A folio volume containing the original manuscripts of forty-six of these essays was acquired by Rutgers in $1901 .^{7}$ Princeton also owns the manuscripts of some political essays, including "On the Clamor Against Lawyers," "On Public Service," and "On the Embargo Act." The Princeton collection is more revealing for Paterson's early life. It includes his poems, college compositions, and correspondence with his college friend John MacPherson, who was also studying law. The two young men discussed their feelings about their 
education - Paterson writing "To be a complete lawyer is to be versed in the feudal system, and to say truth, I am not very fond of being entangled in the cobwebs of antiquity." John MacPherson died in 1776 in the unsuccessful attack against the British in Quebec. The Paterson collections at both Princeton and Rutgers have been extensively used by scholars, most notably by John O'Connor in his William Paterson: Lawyer and Statesman, published in 1979, but as O'Connor notes, there is still material for further work.

Both the Rutgers and Princeton manuscript collections are rich sources of nineteenth-century political history. For instance, both contain the papers of several interconnected New Jersey political figures from the antebellum period. One of these was U.S. Senator Garrett Wall (1783-1850). Wall originally trained as an attorney, practicing in Burlington, New Jersey. He served in the War of 1812, commanding a volunteer regiment from Trenton. He held many state positions including clerk of the State Supreme Court from 1812 to 1817, quartermaster general from 1815 to 1837 , and member of the state general assembly in 1827. In 1829, Wall was elected governor of New Jersey by the legislature, which had this power under the 1776 constitution. He actually declined to serve, preferring to accept a more lucrative appointment as federal district attorney for New Jersey. ${ }^{9}$ In 1835 , he was elected as a Jacksonian to the U.S. Senate, where he served as the chairman of the Committee on the Militia, the Committee on the Judiciary, and the Committee on Military Affairs. Losing the seat in 1841, Wall returned to his legal practice, and in 1848 was appointed to the highest court in New Jersey, the Court of Errors and Appeals, where he served until his death in 1850 .

Princeton possesses a collection of Wall's papers numbering approximately 3,000 items consisting of correspondence received on legal matters and letters written while he was in the Senate, including letters to Governor Peter Vroom. Rutgers also possesses a substantial collection of Wall's papers, including letters dating from when he was a law student and much business and legal correspondence. The papers encompass the correspondence of his son James Wall (1820-1872), who also served briefly as a senator.

In 1840, Garrett Wall's daughter Matilda married Peter DuMont Vroom, Jr. (1791-1873), former governor, who at that time was serving in the House of Representatives. Although Vroom was Wall's son-in-law, the two men were near-contemporaries and both became leaders of the Jacksonian party in New Jersey. ${ }^{10}$ Vroom graduated from Columbia 
College, and like Wall became an attorney. The two men's careers had many parallels; although both began as Federalists in 1824, when the Republican party split, they supported Andrew Jackson. Although he too was at first reluctant to become a candidate, Vroom was elected governor in 1829 after Wall declined the office, serving from 1829 to 1832, and from 1833 to 1836.

Peter Vroom was able to accomplish a great deal as governor in spite of the weakness of the office at this time - the governor had to be reelected annually and possessed no veto power over the state legislature. He worked toward penal reform, building a prison in Trenton, and abolishing imprisonment for debt. He also helped bring about the end of mandatory militia training, sought to make the tax system more equitable by shifting some of the burden from farmers to merchants, and was able to push through legislation improving access to free public education. Under Vroom's administration, the Camden and Amboy Railroad and the Delaware and Raritan Canal companies, which contributed greatly to the economic development of the state, were both chartered, and Vroom supported a merger of the two companies in 1830. In his last term in office however, Vroom began to support state restrictions on corporations, particularly on banks. Although he was in favor of enterprise, he feared that banks contributed to economic instability, and opposed the special privileges banks held in comparison to private individuals. At this time, the governor also served as chancellor of the Court of Chancery; in this position, Vroom made several important decisions which became precedents for future courts.

In 1838, Peter Vroom was elected to the U.S. House of Representatives, and after a disputed election, known as the Broad Seal War, was seated in 1839 , serving until 1841 . In 1844 , he was a delegate to the convention that framed a new constitution for New Jersey, which, with Vroom's support, strengthened the power of the governor. Although no longer in office, Vroom continued to be active in the Democratic party. In 1853, President Franklin Pierce appointed him minister to the court of Prussia, where he remained until 1857.

Princeton possesses a small selection of Vroom's papers in its New Jersey Miscellany collection. These papers mostly concern his legal practice, pertaining to cases in which he was involved such as disputes over the Delaware and Raritan Canal and the Trenton Delaware Falls Company. Rutgers owns a larger collection, some of which is held as part of the Charles A. Philhower papers. Vroom's papers include correspondence concerning his legal practice, as well as correspondence from the 
period when he was U.S. minister to Prussia. In addition, the collection contains the papers of his father, Peter DuMont Vroom, Sr., also a politician, who occupied almost every office in Somerset County, including sheriff and Justice of the Peace.

Princeton also owns an important collection of one of Vroom's political rivals, Samuel Southard (1787-1842), who became leader of the Whig party in New Jersey. Southard, who graduated from Princeton in 1804 , served in the U.S. Senate from 1821 to 1823 , when he was appointed as Secretary of the Navy by President James Monroe. When Southard's party, the National Republicans (later the Whigs), briefly wrested control of the state away from the Jacksonians, Southard was elected governor. Like Garrett Wall, he set little store by the office, leaving after four months to become again a Senator, an office he held until his death. At Rutgers can be found drafts of letters written by Southard to John Calhoun, James Monroe, and James Fenimore Cooper.

\section{Trentieth-Century Political Manuscripts}

One of Rutgers' most important collecting areas is twentieth-century New Jersey public figures. Among the most significant collections are the papers of Clifford $P$. Case, documenting his service as congressman from 1945 to 1953 , and as senator from 1954 to 1979 . During the interim 1953-1954, he was president of the Fund for the Republic, a nonprofit educational corporation which examined "the impact on freedom and justice of corporations, labor unions, and the mass media," the records of which are in the Mudd Library at Princeton. The Rutgers library also possesses the papers of Governor James Florio, Senator Harrison A. Williams, and Democratic Congressman James J. Howard, as well as the papers of two women politicians: Mary Norton, Democratic congresswoman from Jersey City from 1925 to 1951 , and Republican representative Millicent Fenwick.

Although the Seeley G. Mudd Manuscript Library at Princeton is primarily known as a national collection on twentieth-century statecraft, it also holds the papers of several New Jersey public figures. Most prominent are the papers of Woodrow Wilson. This collection contains letters referring extensively to the period before Wilson became president of the United States in 1912, including his tenure as governor of New Jersey and president of Princeton. Another significant collection which is not widely known are the papers of $\mathrm{H}$. Alexander Smith, Republican senator from New Jersey from 1944 to 1959. Smith graduated from Princeton in 1901. He studied law at Columbia and served in 
the United States Food Administration during the First World War and was a member of post-war relief organizations. He was executive secretary of Princeton University from 1919 to 1927 , and lectured in the department of politics from 1927 to 1930 . The records mainly concern his work on the Senate Foreign Relations Committee (1946-1959), where he served with Case for several years, and include a handwritten diary kept by Smith for almost thirty years.

The Mudd Library also holds the papers of Frank Thompson, Democratic congressman from Mercer County from 1955 to 1980. This collection documents his work on the House Education and Labor Committee, where he sponsored legislation to create a national program of domestic volunteers, that became VISTA. Thompson was also a strong supporter of the National Endowment for the Arts and Humanities, which was founded in 1964. Also at Princeton are the papers of his colleague on the Education and Labor Committee, Peter H.B. Frelinghuysen, who served as a Republican congressman from 1953 to 1975. The papers of Frelinghuysen's cousin Joseph Sherman Frelinghuysen, New Jersey Republican senator from 1917 to 1923 are held at Rutgers.

Among the major holdings of the Mudd Library are the archives of the American Civil Liberties Union. Originally housed in the New York Public Library, these were given to Princeton by the ACLU in 1954. The collection includes almost 1,900 scrapbooks and about a thousand cartons. In addition, the library holds the papers of ACLU director Roger Baldwin; counsel Arthur Garfield Hays; Peggy Lamson, author of Roger Baldwin: Founder of the American Civil Liberties Union; and socialist presidential candidate Norman Thomson, who was also a founder of the ACLU. The ACLU archives have not hitherto been seen as a source for New Jersey history. The collection however, encompasses the records of the New Jersey ACLU and other state chapters, as well as documenting the major cases in which the ACLU was involved in New Jersey, such as the Paterson and Passaic strikes and the fight against Mayor Frank Hague of Jersey City. The correspondence, newspaper clippings, and other documents in the scrapbooks are divided by state, and include a wealth of material on New Jersey. The Hays and Baldwin papers also document their involvement in civil liberties cases in New Jersey.

The American Civil Liberties Union grew out of the American Union Against Militarism, which was founded in 1914 to oppose America's entry into the First World War. The organization's leaders were devastated when President Wilson brought the country into the war in early 
1917 and introduced the draft. AUAM members Roger Baldwin and Crystal Eastman established the National Civil Liberties Bureau in 1917, which served initially as a clearinghouse for information about conscription, and tried to defend freedom of speech in the fraught wartime atmosphere. In this capacity, the bureau investigated the treatment of conscientious objectors in prisons and military training camps, where those who refused to register were sent for court martial, faced long sentences, and were sometimes physically beaten by draftees. ${ }^{11}$ One such place was Camp Dix in Wrightstown, New Jersey, which later became the military base Fort Dix. To give one case as an example, Roger Baldwin was told about Lewis Alverson, a conscientious objector at Camp Dix who was brutally treated.

There is no doubt as to his sincerity. The environment of military pressure has driven him to the first stages of insanity, and we fear that the man will be completely insane before long. ${ }^{12}$

Through Baldwin's intervention, a medical discharge was arranged for Private Alverson, who was found to be suffering from "dementia praecox." 13

When the draft was extended to men up to the age of thirty-five, Baldwin found himself eligible. He registered for the draft and chose to go to prison rather than serve. In prison, Baldwin, a Harvard graduate and former social worker, undertook an ambitious reading and writing program. Initially confined in the Essex County prison in Newark, he was later moved to a penitentiary in Caldwell, New Jersey, when he tried to organize a prisoners' self-help group. He became a sort of cause célèbre, effectively publicizing the principles of the Civil Liberties Bureau. After he was released in late 1919, Baldwin reorganized the Civil Liberties Bureau and renamed it the American Civil Liberties Union.

The first major free speech victory for the ACLU in the courts took place in New Jersey. In 1924, 8,000 silk workers went out on strike in Paterson, New Jersey. In response, the mill owners obtained a series of injunctions which banned picketing and prevented the strikers from congregating in groups, effectively suppressing strike-related activity in the city. The silk workers' union turned to the ACLU for help. Baldwin arranged a free speech demonstration on the steps of city hall in Paterson. The police arrested union leader John Butterworth, and Baldwin turned himself in the next day, explaining that he had helped organize the demonstration. Baldwin was convicted under a 1796 statute against unlawful assembly. Fearing another jail term for their director, 
the ACLU attorneys appealed, and in a major victory for the ACLU, the New Jersey Court of Errors and Appeals unanimously reversed his conviction on the grounds that freedom of speech and assembly were protected by the First Amendment. The entire episode is documented in the ACLU archives, as are a number of other strikes and incidents where the right to freedom of speech was challenged in Paterson, Passaic, Newark, and other New Jersey towns.

During the interwar period, the ACLU usually referred cases dealing with racial discrimination to the NAACP. They did keep records however, of such incidents in New Jersey and other states. The ACLU was concerned about the use of the "third degree," beatings and torture of prisoners by the police in order to elicit information, which was sometimes used against African Americans. One such case was that of Richard Fisher, of Salem, New Jersey. When he claimed he knew nothing about a series of robberies, the police "took him to a morgue...lifted him into a coffin, laid him out, living though he was, and clamped the coffin lid down." ${ }^{14}$ During this period, many public places in New Jersey were segregated. For instance, the attention of the ACLU was drawn to an incident where an African-American woman was pulled forcibly out of a seat in the white section of an Atlantic City theater, dislocating her shoulder. The ACLU cooperated with the Atlantic City Civil Rights Enforcement League in this case. In the 1950s and 1960s, the ACLU would play an important role in civil rights litigation.

The ACLU archives also fully document the battle against Jersey City mayor and Democratic political boss Frank Hague. In the 1930s, Hague attempted to attract businesses to Jersey City by suppressing labor unions, particularly the Congress of Industrial Organizations (CIO), through denying meeting permits and allowing police harassment of strikers. The ACLU first took on Hague in 1934, when board member Corliss Lamont was arrested for picketing; a number of clashes followed over the next three years. Finally, in 1938, ACLU counsel Morris Ernst sought and obtained an injunction from District Court Judge William Clark, ordering the city to stop interfering with union activity on the grounds that the ACLU and CIO were lawful organizations. The Supreme Court eventually upheld the injunction against Hague, vindicating First Amendment rights and the ACLU.

The ACLU's commitment to First Amendment rights for everyone meant that they sometimes defended people whom they themselves found reprehensible. This conflict became particularly apparent in the 1930 s with the emergence of Fascist groups in the United States. During 
this period, thousands of people attended the rallies of the pro-Nazi German-American Bund, which was active in New York and New Jersey. Under a 1933 New Jersey law prohibiting speech "advocating hatred, abuse, violence, or hostility against any group or groups of persons by reason of race, color, religion, or manner of worship," Fascist sympathizers were prevented from speaking or distributing propaganda. ${ }^{15}$ The ACLU challenged the arrests of Bund leaders throughout the 1930s. In one instance, the New Jersey Civil Liberties Union declared:

Although the NJCLU differs with the stand and entire philosophy of the Bund, it nevertheless feels that the rights for verbal speech are the rights of our citizens. It feels that the request by the authorities that the future meeting be withheld evades the responsibility of protecting the rights of free speech of American citizens. ${ }^{16}$

The ACLU filed, as a test case, the indictment of ten Bund members for possession of Anti-Semitic literature. The New Jersey Supreme court eventually declared the law unconstitutional in late 1941 under both the First Amendment and the New Jersey Constitution. The ACLU's defense of such people continues, however, to be controversial today.

The use of the ACLU archives at Princeton for information about New Jersey labor history and civil rights illustrates how researchers often find sources in unexpected places. This article has attempted to point out some of these connections in relation to New Jersey history. Although Princeton University is not known for its New Jersey collections, it does possess a great deal of valuable material, some of which is complementary to the strong collection at Rutgers. In the future, while Princeton will primarily build on its current collection strengths, it will undoubtedly continue to acquire some New Jersey material. Rutgers, on the other hand, will maintain and develop its New Jersey collection, as well as extending the scope of its collection policy into new areas. 


\section{NOTES}

1. Richard M. Ludwig, "Looking Backward: The Department of Rare Books and Special Collections since 1953," Princeton University Library Chronicle, 36, No. 3 (Spring 1975).

2. Nancy Bressler, "The Seeley G. Mudd Manuscript Library: A Home Fit for Statesmen," Princeton University Library Chronicle, 39, no. 1 (Autumn, 1977).

3. Peter Charanis, "Donald F. Cameron," The Journal of the Rutgers University Library, 29, No. 2 (June 1966), p. 36.

4. See Richard Cook, "Lewis Morris: New Jersey's Poet-Governor," Journal of the Rutgers University Libraries, 24, No. 3 (June 1961), pp. 100-113.

5. Elias Boudinot to Hannah (Stockton) Boudinot (Jan. 4, 1778), Stimson Boudinot Collection, Department of Rare Books and Special Collections, Princeton University.

6. William Paterson to Euphemia Paterson (July 11, 1787), Folder 12, Paterson Collection, Department of Special Collections and Archives, Rutgers University.

7. Richard P. McCormick, "Political Essays of William Paterson," Joumal of the Rutgers University Library, 18, No. 2 (June 1955), 38-49 and Maxine Lurie, "New Jersey Intellectuals and the United States Constitution," Journal of the Rutgers University Libraries, 49, No. 2 (December 1987), pp. 65-87.

8. William Paterson to John MacPherson (January 17, 1767), Box 1, Paterson Collection, Department of Rare Books and Special Collections, Princeton University Library.

9. Paul A. Stellhorn and Michael J. Birkner, eds., The Governors of New Jersey ('Trenton, 1982), p. 99.

10. See Michael J. Birkner, "Peter Vroom and the Politics of Democracy," in Paul Stellhorn, ed., Jacksonian New Jersey (Trenton, 1979).

11. Samuel Walker, In Defense of American Liberties: A History of the ACLU (New York, 1990), p. 24.

12. R. J. Vrama to Roger Baldwin (July 30, 1918), Volume 5, Reel 1, ACLU Papers, Seeley G. Mudd Library, Princeton University.

13. H.R. Beery to J.W. Van Dusen (August 15, 1918), Volume 5, Reel 1, ACLU Papers, Seeley G. Mudd Library, Princeton University.

14. New York World Telegram (May 2, 1933), v. 665, p. 213, ACLU Papers, Seeley G. Mudd Library, Princeton University.

15. Walker, p. 117.

16. Press release (November 1, 1938), v. 2039, ACLU Papers, Seeley G. Mudd Library, Princeton University. 